\title{
Baclofen/Amitriptyline/Ketamine Gel
}

National Cancer Institute

\section{Source}

National Cancer Institute. Baclofen/Amitriptyline/Ketamine Gel. NCI Thesaurus. Code C67261.

A topical preparation of baclofen, amitriptyline, and ketamine compounded in a penetration-enhancing polaxamer-lecithin organogel (PLO) with potential antineuralgic activity. The gamma-aminobutyric acid (GABA) analogue baclofen appears to activate the inhibitory $G A B A(B)$ receptor, a G protein-coupled receptor, which may result in hyperpolarization of the neuronal cell membrane and inhibition of neurotransmitter release. Amitriptyline likely produces antineuralgic effects via modulation of multiple subtypes of glutamate (Glu) receptors, independent of its antidepressant actions. Ketamine displays complex pharmacologic actions including biogenic amine uptake inhibition, interaction with opioid receptors, and inhibition of N-methyl D-aspartate (NMDA) receptors. Stimulation of GABA(B) receptor activity, modulation of Glu receptor activity, and inhibition of NMDA receptor activity may be of benefit in managing neuropathic pain. 